University of Montana

ScholarWorks at University of Montana

\title{
Linking Direct and Indirect Data on Dispersal: Isolation by Slope in a Headwater Stream Salamander
}

Winsor H. Lowe

University of Montana - Missoula, winsor.lowe@umontana.edu

Gene E. Likens

Mark A. McPeek

Don C. Buso

Follow this and additional works at: https://scholarworks.umt.edu/biosci_pubs

Part of the Biology Commons

Let us know how access to this document benefits you.

\section{Recommended Citation}

Lowe, Winsor H.; Likens, Gene E.; McPeek, Mark A.; and Buso, Don C., "Linking Direct and Indirect Data on Dispersal: Isolation by Slope in a Headwater Stream Salamander" (2006). Biological Sciences Faculty Publications. 276.

https://scholarworks.umt.edu/biosci_pubs/276

This Article is brought to you for free and open access by the Biological Sciences at ScholarWorks at University of Montana. It has been accepted for inclusion in Biological Sciences Faculty Publications by an authorized administrator of ScholarWorks at University of Montana. For more information, please contact scholarworks@mso.umt.edu. 


\title{
LINKING DIRECT AND INDIRECT DATA ON DISPERSAL: ISOLATION BY SLOPE IN A HEADWATER STREAM SALAMANDER
}

\author{
Winsor H. Lowe, ${ }^{1,3}$ Gene E. Likens, ${ }^{1}$ Mark A. McPeek, ${ }^{2}$ And Don C. Buso ${ }^{1}$ \\ ${ }^{1}$ Institute of Ecosystem Studies, Box AB, Millbrook, New York, New York 12545 USA \\ ${ }^{2}$ Department of Biological Sciences, Dartmouth College, Hanover, New Hampshire 03755 USA
}

\begin{abstract}
There is growing recognition of the need to incorporate information on movement behavior in landscape-scale studies of dispersal. One way to do this is by using indirect indices of dispersal (e.g., genetic differentiation) to test predictions derived from direct data on movement behavior. Mark-recapture studies documented upstream-biased movement in the salamander Gyrinophilus porphyriticus (Plethodontidae). Based on this information, we hypothesized that gene flow in $G$. porphyriticus is affected by the slope of the stream. Specifically, because the energy required for upstream dispersal is positively related to slope, we predicted gene flow to be negatively related to change in elevation between sampling sites. Using amplified DNA fragment length polymorphisms among tissue samples from paired sites in nine streams in the Hubbard Brook Watershed, New Hampshire, USA, we found that genetic distances between downstream and upstream sites were positively related to change in elevation over standardized $1-\mathrm{km}$ distances. This pattern of isolation by slope elucidates controls on population connectivity in stream networks and underscores the potential for specific behaviors to affect the genetic structure of species at the landscape scale. More broadly, our results show the value of combining direct data on movement behavior and indirect indices to assess patterns and consequences of dispersal in spatially complex ecosystems.

Key words: amphibian; amplified fragment length polymorphism; behavior; dispersal; evolution; gene flow; Gyrinophilus porphyriticus; headwater streams; Hubbard Brook; movement; Plethodontidae; salamander.
\end{abstract}

\section{INTRODUCTION}

Understanding the causes and consequences of animal dispersal may be critical to answering basic ecological and evolutionary questions (McPeek and Holt 1992, Hastings 1993) and to conserving species in human-impacted systems (Mills and Allendorf 1996, Shaffer et al. 2000). However, populations of many species are distributed across spatially complex and heterogeneous landscapes, making it difficult to measure dispersal directly at scales that are relevant to demographic and evolutionary processes. As a result, empirical research on dispersal often relies on indirect inference from genetic data and patterns of spatial or temporal variation in local abundance (Clobert et al. 2001, Bullock et al. 2002). These indirect approaches yield valuable insight, but can mask details of animal movement behavior, including responses to barriers (Haddad 1999) and directional biases (MacNeale et al. 2004). In recognizing the importance of these details to basic and applied questions, there is growing emphasis on the need to incorporate information on move-

Manuscript received 9 February 2005; revised 22 September 2005; accepted 26 September 2005. Corresponding Editor: A. Sih.

${ }^{3}$ Present address: Division of Biological Sciences, University of Montana, Missoula, Montana 59812 USA.

E-mail: winsor.lowe@umontana.edu ment behavior in landscape-scale studies of dispersal (Bossart and Prowell 1998, Clobert et al. 2001, Nathan 2001, Bélisle 2005). One way to do this is by using indirect indices of dispersal to test specific predictions derived from direct data on animal movement behavior.

Spatial patterns of genetic differentiation are often used to characterize dispersal (e.g., Schwartz et al. 2002). In this context, the isolation-by-distance hypothesis, which predicts that gene flow decreases as the distance required for successful dispersal increases (Wright 1943), is well supported (e.g., Chenoweth et al. 1998). This hypothesis is broadly testable and informative in part because any two sampling sites can be characterized by two-dimensional geographic coordinates and a resulting distance. However, the landscape is three dimensional, and distance between any two sites can also be characterized by an elevation profile reflecting intervening topography. These elevation profiles may affect dispersal and gene flow, independent of the effect of distance (e.g., Angers et al. 1999). Our goal was to explore how change in elevation affects gene flow in a headwater stream salamander by testing a prediction derived from direct data on the movement behavior of the focal species.

Using mark-recapture methods, a strong upstream bias in the movement of the headwater stream salamander Gyrinophilus porphyriticus was documented in 16 streams located throughout New Hampshire, USA 
(Lowe 2003; B. J. Cosentino, W. H. Lowe, and G. E. Likens, unpublished manuscript). Both larvae and adults showed this directional bias, and there was no difference between the movement distributions of the two life history stages. This data set includes two streams in the Hubbard Brook Watershed where sampling for the current study occurred. G. porphyriticus is a member of the family Plethodontidae, the lungless salamanders. Its range extends along the Appalachian Mountains, from Alabama to southern Quebec. G. porphyriticus larvae are strictly aquatic, but adults can be found both in the channel and along the edge of the stream (Bishop 1941, Petranka 1998). The larval period is three to five years, sexual maturity occurs within one year after metamorphosis (Bishop 1941, Bruce 1972), and maximum life span in New Hampshire was estimated to be approximately 10 years (Lowe 2003).

Based on our understanding of the movement behavior of $G$. porphyriticus we hypothesized that dispersal and gene flow are influenced by the slope of the stream, as represented by change in elevation between sampling sites. More specifically, because gravity dictates that the energy required for upstream dispersal is positively related to the slope of the stream over a given distance, we predicted gene flow to be negatively related to change in elevation along the stream. This relationship is likely to have the strongest effect on genetic differentiation in species that are highly restricted to the stream corridor, reducing the likelihood that overland dispersers contribute to gene flow, and in which downstream movement occurs infrequently or at small spatial scales (Bunn and Hughes 1997). Anecdotal reports suggest that adults of $G$. porphyriticus can be found moving overland in the southern Appalachians (R. C. Bruce and H. M. Wilbur, personal communication). However, diet data from New Hampshire indicate that $G$. porphyriticus adults are highly aquatic (Lowe et al. 2005), and a study conducted at four streams in the Hubbard Brook Watershed in 2004 found that terrestrial movement by adults was restricted to within $2 \mathrm{~m}$ of the stream edge (B. T. Greene, W. H. Lowe, and G. E. Likens, unpublished data). Downstream movement by larvae and adults of G. porphyriticus occurs significantly less frequently and over shorter distances than upstream movement ( $\leq 85 \mathrm{~m}$ vs. $\leq 484 \mathrm{~m}$ in a 3 -yr interval, respectively; Lowe 2003).

We collected $G$. porphyriticus tissue samples at paired sites in nine hydrologically independent streams distributed throughout the Hubbard Brook Watershed. In each stream, downstream and upstream sites were separated by $1 \mathrm{~km}$, measured along the stream channel. Change in elevation over this distance varied as a function of drainage topography. We used the amplified fragment length polymorphism (AFLP) technique to characterize genetic variation at each site (Vos et al. 1995), and we used regression analysis to assess the relationship of genetic distance between downstream and upstream sites to change in elevation.

\section{Methods}

\section{Study sites and tissue collection}

The $31.6 \mathrm{~km}^{2}$ Hubbard Brook Experimental Forest (HBEF), located within the White Mountains of central New Hampshire, USA ( $43^{\circ} 56^{\prime}$ N, $\left.71^{\circ} 45^{\prime} \mathrm{W}\right)$, comprises all but a small portion of the Hubbard Brook Watershed (Fig. 1). In June, July, and August of 2003, we sampled salamanders in nine hydrologically independent streams on both south- and north-facing aspects of the Hubbard Brook Watershed. The study streams were selected to represent a range of drainage slopes. Typical of headwater streams in New Hampshire, the study streams have low conductivity $(12.0-15.0 \mu \mathrm{S})$, slight acidity ( $\mathrm{pH}$ of 5.0-6.0), high dissolved oxygen content (80-90\% saturation), and moderate midday summer temperatures $\left(13.0-17.0^{\circ} \mathrm{C}\right)$ (Likens and Bormann 1995).

Tissue samples were collected from G. porphyriticus individuals at two sites (each $100 \mathrm{~m}$ in length) in each stream. Based on distance measured along the stream, downstream sites were comprised of the reach between 100 and $200 \mathrm{~m}$ from the downstream confluence of the study stream with a higher-order stream (Fig. 1). Upstream sites were comprised of the reach between 1200 and $1300 \mathrm{~m}$ from this downstream confluence. Consequently, downstream and upstream sites were separated by $1 \mathrm{~km}$ along the stream, but change in elevation over this distance varied as a function of the topography of the drainages. Ten individuals were sampled at 16 sites and nine individuals were sampled at two sites (downstream in Zigzag East and upstream in Cascade). Ratios of larvae to adults sampled were between 0.67 and 1.5 to 1 , and there were no differences among streams or between downstream and upstream sites in these values (two-way analysis of variance [ANOVA]; stream effect, $F_{8,8}=0.43, P=0.56$; site effect, $F_{1,8}=$ $0.36, P=0.56)$. We obtained tissue samples nonlethally by removing a small piece from the tip of animal's tail, which subsequently regrows. Tissue was placed in $90 \%$ ethanol and stored at $-80^{\circ} \mathrm{C}$.

\section{AFLP amplification and scoring}

Total DNA was extracted from tissue samples using standard phenol extraction methods. The AFLP loci were developed using the manufacturer's instructions with the AFLP Plant Mapping Kit (Applied Biosystems [ABI], Foster City, California, USA). Loci from the Eco RI-ACA primer labeled with the FAM fluorochrome paired with the Mse I-CAC primer were selectively amplified. Amplified products were run on an ABI 3100 sequencer, and AFLP peaks were categorized and scored using the ABI Genotyper v3.0 software. We identified a total of 92 polymorphic loci among the 178 individuals sampled. We determined that AFLP peak profiles were highly repeatable in estimated sizes and fluorescence intensity by performing duplicate reactions on 15 randomly selected samples.

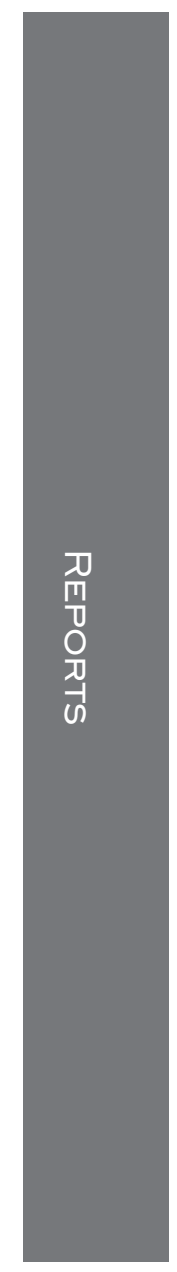



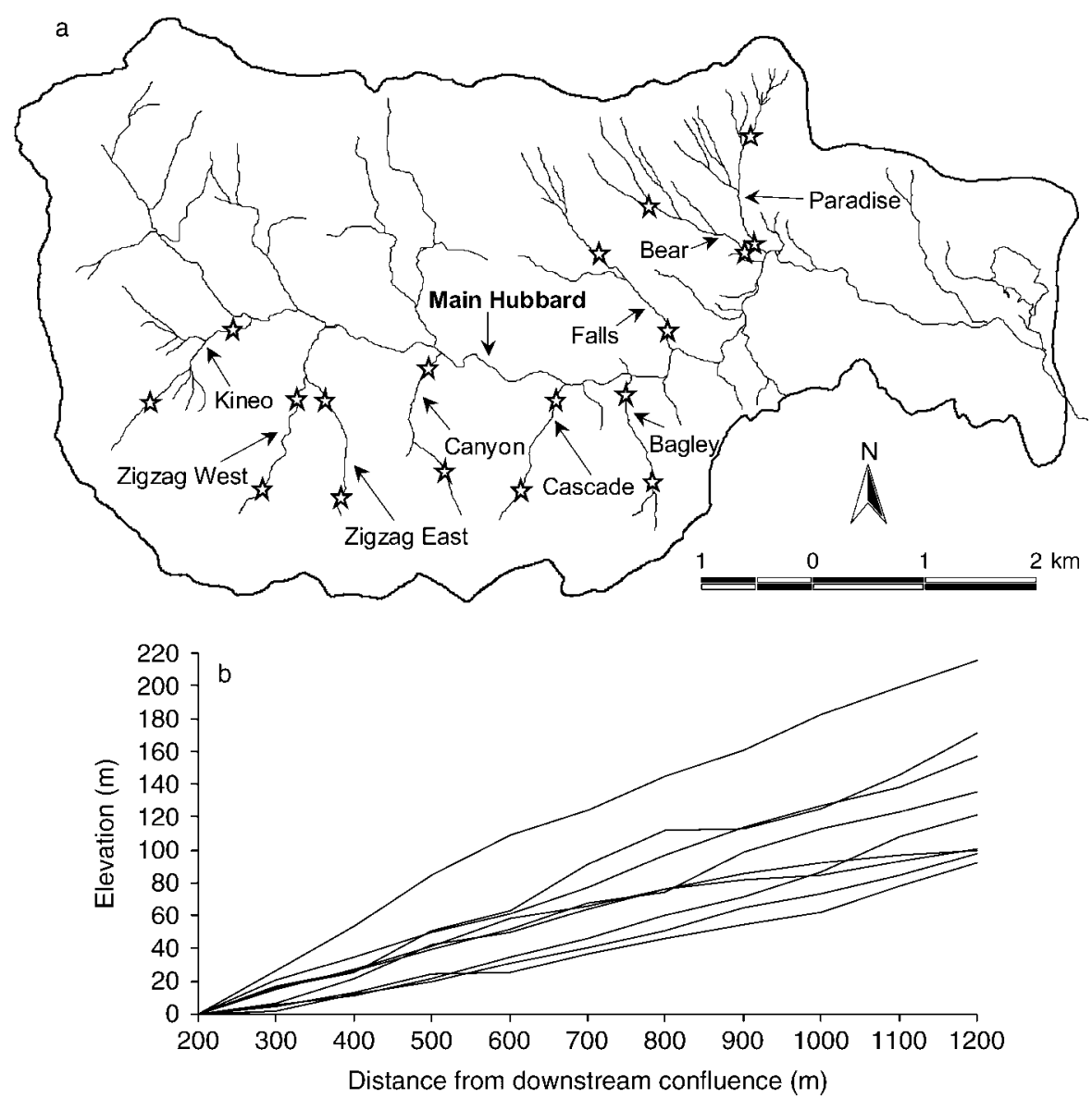

FIG. 1. (a) Map of the Hubbard Brook Experimental Forest, New Hampshire, USA, which comprises the majority of the Hubbard Brook Watershed. Study streams and the main Hubbard Brook are labeled. Stars indicate the locations of sites where Gyrinophilus porphyriticus tissue samples were collected. Sampling sites within each stream were $1 \mathrm{~km}$ apart, measured along the stream. (b) Standardized elevation profiles between downstream and upstream sampling sites in the nine study streams based on elevation measurements taken every $100 \mathrm{~m}$ of stream length. The profiles correspond to the following streams, in order of increasing change in elevation between downstream and upstream sampling sites: Zigzag West, Zigzag East, Bagley Trail, Falls, Kineo, Bear, Paradise, Canyon, Cascade.

\section{AFLP analyses}

Because AFLP markers are dominant loci, the assumption of Hardy-Weinberg equilibrium is often made to analyze genetic diversity and genetic structure using these markers (Holsinger et al. 2002). We used analytical techniques that do not rely on this assumption, but do assume that deviations from Hardy-Weinberg equilibrium and from linkage equilibrium are similar across sites. To increase confidence in our results, we also used two different metrics of genetic distance: $\Phi_{\mathrm{ST}}$ and $\theta^{\mathrm{B}}$ (Excoffier et al. 1992, Holsinger et al. 2002). Both metrics are analogous to $F_{\mathrm{ST}}$ at the molecular level (Wright 1951), describing the level of genetic divergence between sites within streams.

Pairwise $\Phi_{\text {ST }}$ values for downstream and upstream sites within each stream were estimated using the analysis of molecular variation (AMOVA) framework implemented in WINAMOVA v1.55 (Excoffier et al. 1992). This procedure uses pairwise Euclidian dis- tances among AFLP marker profiles for analyses, and does not require indirect estimates of allele frequencies. The distance matrix and other input files needed for AMOVA were produced using AMOVA-PREP v1.1 (Miller 1997a). We used the Bayesian method developed by Holsinger et al. (2002) to estimate pairwise $\theta^{\mathrm{B}}$ statistics for downstream and upstream sites. These analyses were performed using Hickory v1.0.3 (Holsinger and Lewis 2003). The Hickory program was also used to estimate average heterozygosities at each site. Percentages of polymorphic loci at each site were obtained using Tools for Population Genetic Analysis (TFPGA) v1.3 (Miller 1997b).

Change in elevation $(\mathrm{m})$ for paired sites in each stream was calculated as the difference between the maximum elevation of the downstream site (i.e., at the upstream end) and the minimum elevation of the upstream site (i.e., at the downstream end). Geographic coordinates for points every $100 \mathrm{~m}$ along the study 
streams were obtained using a global positioning system receiver (Garmin, Olathe, Kansas, USA). The elevations of these points were determined using Terrain Navigator software (MAPTECH, Amesbury, Massachusetts, USA) with an enhanced digital elevation model of the Hubbard Brook Watershed (Fig. 1).

Linear regression analysis was used to test the prediction that genetic distance $\left(\Phi_{\mathrm{ST}}\right.$ and $\left.\theta^{\mathrm{B}}\right)$ is positively related to change in elevation between downstream and upstream sites. To meet the assumption of normality, change in elevation was square-root transformed. Assuming a stepping-stone model at drift/migration equilibrium, a positive relationship between genetic distance and change in elevation would indicate that gene flow decreases with increasing slope (Kimura and Weiss 1964). To assess variation in G. porphyriticus genetic diversity throughout the watershed, we used two-way ANOVA to test for differences among streams and between downstream and upstream sites in average heterozygosity and percentage of polymorphic loci.

To test the assumption that dispersal by $G$. porphyriticus occurs predominantly along the stream corridor, pairwise $\Phi_{\mathrm{ST}}$ values were estimated for all combinations of sampling sites (153 pairwise comparisons). The time required to estimate $\theta^{\mathrm{B}}$ for all pairs of sampling sites was prohibitively long. We used the Terrain Navigator software to calculate pairwise overland distances (i.e., straight-line distances) and stream distances (i.e., shortest distances along stream corridors) for all sites. We then used the Mantel matrix correspondence test (Mantel 1967), implemented with the TFPGA program, to test for correlation of pairwise genetic distances with both overland and stream distances $(\mathrm{m})$. Overland and stream distances were squareroot transformed to increase normality. Pairwise $\Phi_{\mathrm{ST}}$ values were predicted to be positively related to stream distances and unrelated to overland distances.

\section{RESUltS}

Both $\Phi_{\mathrm{ST}}$ and $\theta^{\mathrm{B}}$ were positively related to change in elevation between downstream and upstream sites in the nine study streams $\left(\Phi_{\mathrm{ST}}, F_{1,7}=11.69, P=0.01\right.$, $r^{2}=0.63 ; \theta^{\mathrm{B}}, F_{1,7}=11.17, P=0.01, r^{2}=0.61$; Fig. 2). Because sampling sites in each stream were $1 \mathrm{~km}$ apart, measured along the stream, these relationships between change in elevation and genetic differentiation are independent of stream distance. There were no differences among streams or between downstream and upstream sites in average heterozygosity (stream effect, $F_{8,8}=0.9, P=0.56$; site effect, $F_{1,8}=0.3, P=0.6$; Appendix) and percentage of polymorphic loci (stream effect, $F_{8,8}=1.09, P=0.45$; site effect, $F_{1,8}=1.08$, $P=0.33$ ). Across all sites (153 pairwise comparisons), there was a significant positive relationship between stream distances and $\Phi_{\mathrm{ST}}$ values (Mantel matrix correlation: $r=0.23, P=0.02)$ and no relationship between overland distances and $\Phi_{\mathrm{ST}}$ values $(r=0.14, P$ $>0.05)$.
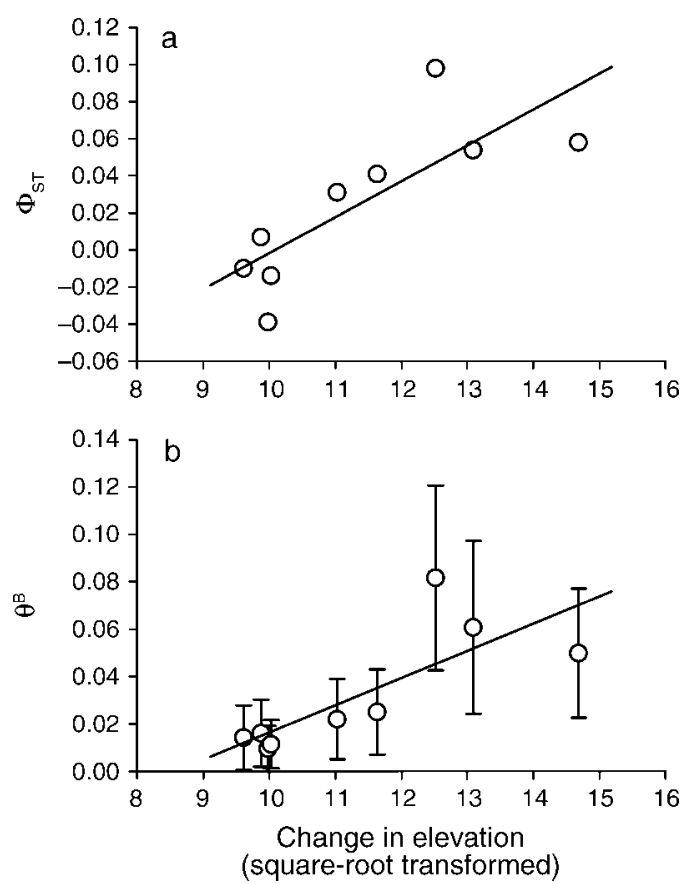

FIG. 2. The relationship of genetic distance, represented by (a) $\Phi_{\mathrm{ST}}$ and (b) $\theta^{\mathrm{B}}$ (mean $\pm \mathrm{SD}$ ), to change in elevation ( $\mathrm{m}$, square-root transformed) between downstream and upstream sites in nine streams where Gyrinophilus porphyriticus tissue samples were collected. Downstream and upstream sites were separated by $1 \mathrm{~km}$ of distance along the streams (see Fig. 1). Least-squares regression lines are plotted.

\section{DISCUSSION}

Mark-recapture studies revealed the strong upstream bias in G. porphyriticus movement (Lowe 2003), and this information allowed us to predict that gene flow would be negatively related to change in elevation along nine streams in the Hubbard Brook Watershed (Fig. 2). Variation in gene flow was observed at the scale of $1 \mathrm{~km}$ along the study streams, suggesting that the predicted effect of slope on the movement of $G$. porphyriticus was highly consistent in space and time. There was no difference among streams or between downstream and upstream sites in genetic diversity, quantified as average heterozygosity and percentage of polymorphic loci, suggesting that demographic histories for processes that could influence genetic diversity at these sites (e.g., population bottlenecks and demographic expansions) have been similar over the recent past (Hartl and Clark 1997), and that natural selection may maintain local genetic diversity when gene flow is low. In addition to this evidence of similar demographic histories, repeated surveys conducted in three of the study streams (Bagley Trail, Canyon, and Cascade) in 2004 suggest that current abundances of $G$. porphyriticus do not differ among these streams, or between downstream and upstream sites within these streams (W. H. Lowe and G. E. Likens, unpublished data). Our analysis of isolation by distance supported

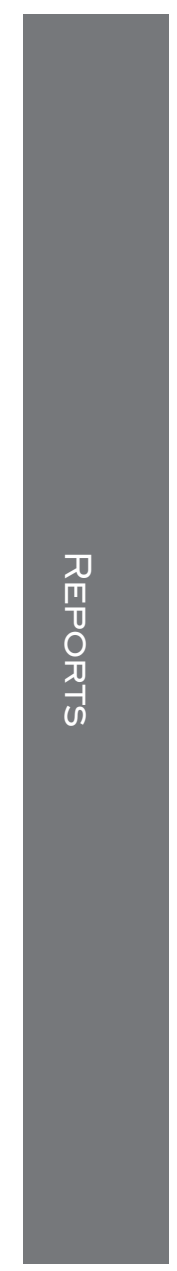


the assumption that dispersal by $G$. porphyriticus occurs primarily along the stream corridor.

Along with direct data showing that downstream movement by larvae and adults of $G$. porphyriticus is rare (Lowe 2003, B. J. Cosentino, W. H. Lowe, and G. E. Likens, unpublished manuscript), the consistency of genetic diversity across sites refutes the alternative hypothesis that variation in gene flow along the nine study streams was related to variation in rates of downstream movement. If downstream movement, or drift, were an important mechanism of gene flow in this species, we would expect to see a trend toward higher genetic diversity at downstream sites due to contributions from multiple, independent first-order tributaries that join the main channels of five of the study streams between sampling sites (Fig. 1). An assignment test could be used to determine the precise contributions of upstream and downstream gene flow to the observed pattern of differentiation (Berry et al. 2004), and we are currently collecting the additional samples needed to perform this test.

As in cases where genetic data support the isolationby-distance hypothesis, the relationship between slope and gene flow observed in G. porphyriticus cannot be linked to a specific mechanism of isolation on the basis of our results (Manel et al. 2003). Our prediction was based on the expected direct effect of slope (i.e., gravity) on dispersal, but this relationship may have resulted from factors limiting gene flow that were correlated with slope, such as elevational variation in aquatic conditions, reaches with high predator densities, or other features of the landscape. We are currently examining relationships between genetic differentiation in G. porphyriticus and elevational trends in 17 aquatic conditions (e.g., water temperature, dissolved oxygen, acidity) measured every $100 \mathrm{~m}$ along the $1 \mathrm{~km}$ separating downstream and upstream sites in the nine study streams (G. E. Likens and D. C. Buso, unpublished data). Preliminary results indicate that the observed pattern of genetic differentiation is unrelated to spatial variation in these conditions. Brook trout (Salvelinus fontinalis), a predator of G. porphyriticus (Lowe and Bolger 2002), are rare in tributaries of the main Hubbard Brook and, when present, are limited to reaches within $100 \mathrm{~m}$ of tributary confluences (D. C. Buso and G. E. Likens, personal observation). Because all of our sampling sites were more than 100 $m$ upstream of confluences with the main Hubbard Brook, brook trout distribution is unlikely to account for the pattern of genetic differentiation observed in $G$. porphyriticus.

In North and South Carolina, Bruce (1972) found that $G$. porphyriticus had larger adult body sizes, later maturity, and lower size-specific fecundity in high elevation populations than in low elevation populations. In this and other cases where plethodontids exhibit genetic or phenotypic variation along elevational gradients (Hairston 1987, Wake 1987), the direct effect of slope on dispersal and gene flow should be examined as a possible mechanism leading to population differentiation. The high level of interest in local adaptation and speciation in plethodontids (e.g., Wake 1997, Mead et al. 2001) further reinforces the value of direct data on the movement behavior of species in this family (Rissler et al. 2004).

The presence of a nearby immigrant source can mitigate the negative effect of logging-associated sedimentation on the abundance of G. porphyriticus (Lowe and Bolger 2002), and dispersal can stabilize local population growth rates (Lowe 2003). Along with these and other studies (e.g., Storfer and Sih 1998, Ferguson 2000), the molecular data presented here underscore the need to consider dispersal in applied and basic research on the population biology of stream amphibians. More broadly, our results show that information on elevation gradients and distance along the stream corridor can be used to manage for population connectivity in stream networks.

This study illustrates the value of using direct data on animal movement behavior to derive predictions that can be tested using indirect indices of dispersal, thereby exploiting the complementarity of these two types of data to build understanding of dispersal in spatially complex ecosystems. It also highlights the applicability of elevation data to analyses of controls on gene flow (Manel et al. 2003), and the potential for specific behaviors (e.g., upstream-biased movement) to affect the genetic structure of species at the landscape scale (King and With 2002). A critical next step in empirical research on animal dispersal is to expand general understanding of how the genetic and phenotypic attributes of individual dispersers affect the largescale consequences of this important demographic and evolutionary process.

\section{ACKNOWLEDGMENTS}

We are grateful for the assistance provided by J. Tollefson, I. Halm, R. Hall, C. Chen, D. Bolger, M. Bolger-Chen, and J. Chen. M. Miller gave us valuable advice on statistical analyses. Financial support was provided by The Andrew W. Mellon Foundation. This manuscript benefited from the comments L. Bernatchez, D. Strayer, M. Uriarte, and three anonymous reviewers. This is a contribution to the Hubbard Brook Ecosystem Study and the Program of the Institute of Ecosystem Studies. The Hubbard Brook Experimental Forest is operated and maintained by the Northeastern Forest Research Station, United States Department of Agriculture Forest Service, Newtown Square, Pennsylvania, USA.

\section{Literature Cited}

Angers, B., P. Magnan, M. Plante, and L. Bernatchez. 1999. Canonical correspondence analysis for estimating spatial and environmental effects on microsatellite gene diversity in brook charr (Salvelinus fontinalis). Molecular Ecology 8:1043-1053.

Bélisle, M. 2005. Measuring landscape connectivity: the challenge of behavioral landscape ecology. Ecology 86: 1988-1995.

Berry, O., M. D. Tocher, and S. D. Sarre. 2004. Can assignment tests measure dispersal? Molecular Ecology 13:551-561.

Bishop, S. C. 1941. Salamanders of New York. New York State Museum Bulletin 324:1-365. 
Bossart, J. L., and D. P. Prowell. 1998. Genetic estimates of population structure and gene flow: limitations, lessons and new directions. Trends in Ecology and Evolution 13:202-206.

Bruce, R. C. 1972. Variation in the life cycle of the salamander Gyrinophilus porphyriticus. Herpetologica 28:230-245.

Bullock, J. M., R. E. Kenward, and R. S. Hails, editors. 2002. Dispersal ecology: the 42nd Symposium of the British Ecological Society. Blackwell, Malden, Massachusetts, USA.

Bunn, S. E., and J. M. Hughes. 1997. Dispersal and recruitment in streams: evidence from genetic studies. Journal of the North American Benthological Society 16:338-346.

Chenoweth, S. F., J. M. Hughes, C. P. Keenan, and L. Shane. 1998. Concordance between dispersal and mitochondrial gene flow: isolation by distance in a tropical teleost, Lats calcarifer (Australian barramundi). Heredity 80:187-197.

Clobert, J., E. Danchin, A. A. Dhondt, and J. D. Nichols, editors. 2001. Dispersal. Oxford University Press, Oxford, UK.

Excoffier, L., P. Smouse, and J. Quattro. 1992. Analysis of molecular variance inferred from metric distances among DNA haplotypes: application to human mitochondrial DNA restriction data. Genetics 131:479-491.

Ferguson, H. M. 2000. Larval colonisation and recruitment in the Pacific giant salamander (Dicamptodon tenebrosus) in British Columbia. Canadian Journal of Zoology 78: $1238-1242$.

Haddad, N. M. 1999. Corridor use predicted from behaviors at habitat boundaries. American Naturalist 153:215-227.

Hairston, N. G. 1987. Community ecology and salamander guilds. Cambridge University Press, Cambridge, UK.

Hartl, D. L., and A. G. Clark. 1997. Principles of population genetics. Sinauer Associates, Sunderland, Massachusetts, USA.

Hastings, A. 1993. Complex interactions between dispersal and dynamics: lessons from coupled logistic equations. Ecology 74:1362-1372.

Holsinger, K. E., and P. O. Lewis. 2003. Hickory v1.0.3: a program for analysis of population genetic data. Department of Ecology and Evolutionary Biology, University of Connecticut, Storrs, Connecticut, USA.

Holsinger, K. E., P. O. Lewis, and D. K. Dey. 2002. A Bayesian approach to inferring population structure from dominant markers. Molecular Ecology 11:1157-1164.

Kimura, M., and G. H. Weiss. 1964. The stepping stone model of population structure and the decrease of genetic correlation with distance. Genetics 49:561-576.

King, A. W., and K. A. With. 2002. Dispersal success on spatially structured landscapes: when do spatial pattern and dispersal behavior really matter? Ecological Modeling 147: 23-39.

Likens, G. E., and F. H. Bormann. 1995. Biogeochemistry of a forested ecosystem. Springer-Verlag, New York, New York, USA.

Lowe, W. H. 2003. Linking dispersal to local population dynamics: a case study using a headwater salamander system. Ecology 83:2145-2154.

Lowe, W. H., and D. T. Bolger. 2002. Local and landscapescale predictors of salamander abundance in New Hampshire headwater streams. Conservation Biology 16:183-193.

Lowe, W. H., K. H. Nislow, and G. E. Likens. 2005. Forest structure and stream salamander diets: implications for terrestrial-aquatic connectivity. Verhandlungen der Internationalen Vereinigung für Theoretische und Angewandte Limnologie 29:279-286.
MacNeale, K. H., B. L. Peckarsky, and G. E. Likens. 2004 Contradictory results from different methods for measuring direction of insect flight. Freshwater Biology 49:1260-1268.

Manel, S., M. K. Schwartz, G. Luikart, and P. Taberlet. 2003. Landscape genetics: combining landscape ecology and population genetics. Trends in Ecology and Evolution 18: 189-197.

Mantel, N. 1967. The detection of disease clustering and a generalized regression approach. Cancer Research 27:209220

McPeek, M. A., and R. D. Holt. 1992. The evolution of dispersal in spatially and temporally varying environments. American Naturalist 140:1010-1027.

Mead, L. S., S. G. Tilley, and L. A. Katz. 2001. Genetic structure of the blue ridge dusky salamander (Desmognathus orestes): inferences from allozymes, mitochondrial DNA, and behavior. Evolution 55:2287-2302.

Miller, M. P. 1997a. AMOVA-PREP v1.1: a program for the preparation of input files for use with WINAMOVA. Department of Biological Sciences, Northern Arizona University, Flagstaff, Arizona, USA.

Miller, M. P. 1997b. Tools for population genetic analysis (TFPGA) v1.3: a windows program for the analysis of allozyme and molecular population genetic data. Department of Biological Sciences, Northern Arizona University, Flagstaff, Arizona, USA.

Mills, L. S., and F. W. Allendorf. 1996. The one-migrantper-generation rule in conservation and management. Conservation Biology 10:1509-1518.

Nathan, R. 2001. The challenges of studying dispersal. Trends in Ecology and Evolution 16:481-483.

Petranka, J. W. 1998. Salamanders of the United States and Canada. Smithsonian Institution Press, Washington, D.C., USA.

Rissler, L. J., H. M. Wilbur, and D. R. Taylor. 2004. The influence of ecology and genetics on behavioral variation in salamander populations across the Eastern Continental Divide. American Naturalist 164:201-213.

Schwartz, M. K., L. S. Mills, K. S. McKelvey, L. F. Ruggiero, and F. W. Allendorf. 2002. DNA reveals high dispersa synchronizing the population dynamics of Canada lynx. Nature 415:520-522.

Shaffer, G., G. M. Fellers, A. Magee, and R. Voss. 2000. The genetics of amphibian declines: population substructure and molecular differentiation in the Yosemite Toad, Bufo canorus (Anura, Bufonidae) based on single-strand conformation polymorphism analysis (SSCP) and mitochondrial DNA sequence data. Molecular Ecology 9:245-257.

Storfer, A., and A. Sih. 1998. Gene flow and ineffective antipredator behavior in a stream-breeding salamander. Evolution 52:558-565.

Vos, P., R. Hogers, M. Bleeker, M. Reijans, T. Vandelee, M. Hornes, A. Frijters, J. Pot, J. Peleman, M. Kuiper, and M. Zabeau. 1995. AFLP: a new technique for DNA fingerprinting. Nucleic Acids Research 23:4407-4414.

Wake, D. B. 1987. Adaptive radiation of salamanders in Middle American cloud forests. Annals of the Missouri Botanical Garden 74:242-264.

Wake, D. B. 1997. Incipient species formation in salamanders of the Ensatina complex. Proceedings of the National Academy of Sciences (USA) 94:7761-7767.

Wright, S. 1943. Isolation by distance. Genetics 28:114-138.

Wright, S. 1951. The genetical structure of natural populations. Annals of Eugenics 15:323-354.

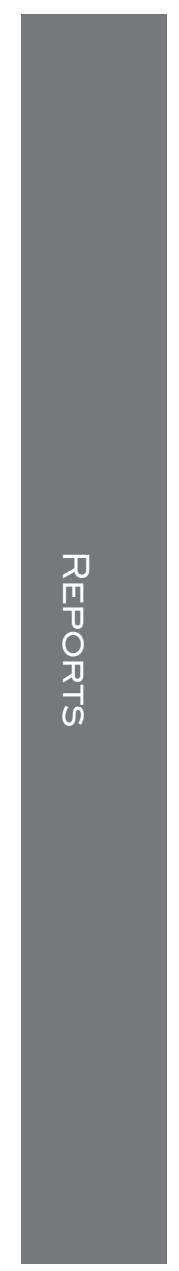

\section{APPENDIX}

A table presenting descriptive statistics for amplified fragment length polymorphism variation at 18 sites in the Hubbard Brook Watershed, New Hampshire, USA, where Gyrinophilus porphyriticus tissue samples were collected (Ecological Archives E087-019-A1). 